\title{
Trophic ecology of common elasmobranchs exploited by artisanal shark fisheries off south-western Madagascar
}

\author{
Jeremy J. Kiszka ${ }^{1,2, *}$, Kevin Charlot ${ }^{1}$, Nigel E. Hussey ${ }^{3}$, Michael R. Heithaus ${ }^{2}$, \\ Benoit Simon-Bouhet ${ }^{1}$, Frances Humber ${ }^{4,5}$, Florence Caurant ${ }^{1}$, Paco Bustamante ${ }^{1}$ \\ ${ }^{1}$ Littoral Environnement et Sociétés (LIENSs), UMR 7266 CNRS-Université de la Rochelle, 2 rue Olympe de Gouges, \\ 17000 La Rochelle, France \\ ${ }^{2}$ Marine Sciences Program, Department of Biological Sciences, Florida International University, 3000 NE $151^{\text {st }}$ Street, \\ North Miami, Florida 33181, USA \\ ${ }^{3}$ Great Lakes Institute for Environmental Research, University of Windsor, 401 Sunset Avenue, Ontario N9B 3P4, Canada \\ ${ }^{4}$ Blue Ventures, Level 2 Annex, Omnibus Business Centre, 39-41 North Road, London N7 9DP, UK \\ ${ }^{5}$ Centre for Ecology and Conservation, College of Life and Environmental Sciences, University of Exeter, Penryn TR10 9FE, UK
}

\begin{abstract}
Knowledge of the trophic ecology and interactions of marine top predators is fundamental for understanding community structure and dynamics as well as ecosystem function. We examined the feeding relationships of 4 heavily exploited elasmobranchs caught in coastal artisanal shark fisheries in south-western Madagascar in 2009 and 2010_Sphyrna lewini, Loxodon macrorhinus, Carcharhinus falciformis and Rhynchobatus djiddensis-using stable isotope $\left(\delta^{15} \mathrm{~N}\right.$ and $\delta^{13} \mathrm{C}$ ) analysis. Relative trophic position (indicated by $\delta^{15} \mathrm{~N}$ ) and foraging location (indicated by $\delta^{13} \mathrm{C}$ ) differed among species. Isotopic niche width was highly variable: more pelagic species, such as $S$. lewini and C. falciformis, had the broadest isotopic niches while the benthic $R$. djiddensis had the narrowest. A high percentage of niche overlap occurred between $R$. djiddensis and 2 of the species, C. falciformis (93.2\%) and L. macrorhinus (73.2\%), and to a lesser extent $S$. lewini $(13.3 \%)$. Relative trophic position of $S$. lewini significantly increased with size, suggesting a dietary shift with age. Sex differences in $\delta^{15} \mathrm{~N}$ values were observed in L. macrorhinus, suggesting intraspecific niche partitioning. Variation in stable isotope values among these 4 highly exploited elasmobranch species indicates trophic structuring, likely driven by differences in diet and habitat use as well as by size and sex. This study provides the first baseline information on the trophic ecology of elasmobranchs caught in artisanal fisheries from south-western Madagascar.
\end{abstract}

KEY WORDS: Artisanal fisheries $\cdot$ Sharks $\cdot$ Trophic ecology $\cdot \delta^{15} \mathrm{~N} \cdot \delta^{13} \mathrm{C} \cdot$ Ontogenetic shift $\cdot$ Sex differences

\section{INTRODUCTION}

Predicting the community-level consequences of changes in the abundance of a particular species, due to natural or anthropogenic factors, requires an understanding of its trophic interactions and trophic similarity amongst species (i.e. the level of trophic

*Corresponding author: jeremy.kiszka@gmail.com redundancy). In both terrestrial and marine environments, the removal of predators across multiple trophic levels has been shown to disrupt ecosystem function (reviewed in Estes et al. 2011). Declines of top marine predators, such as sharks, have been widely documented (Ferretti et al. 2010) and have raised international concern (Dulvy et al. 2008, Worm

(C) The authors 2014. Open Access under Creative Commons by Attribution Licence. Use, distribution and reproduction are unrestricted. Authors and original publication must be credited. 
et al. 2013), but there is a paucity of data regarding trophic relationships among species within this predatory guild. For coastal ecosystems, it has been proposed that predator declines could initiate trophic cascades, whereby their removal disrupts the natural population abundances, or behaviours, of consecutive lower trophic level species (Myers et al. 2007, Heithaus et al. 2008, Burkholder et al. 2013). Elasmobranchs are upper trophic level predators in many marine ecosystems, but there is considerable variation in diets and relative trophic position among species (Wetherbee \& Cortés 2004, Hussey et al. 2014). The presence of a diverse marine top predator community, such as elasmobranchs, including an abundance of sympatric and ecologically interacting species, may be important in structuring some marine communities (Heithaus et al. 2010). It is unclear, however, whether diverse marine top predator faunas represent trophically redundant species (Myers et al. 2007) or inhabit unique foraging niches with differential impacts on overall community structure (Kinney et al. 2011, Heithaus et al. 2013).

Although $95 \%$ of global fishers are artisanal (Pauly 2006), detailed information on fisheries catch composition is limited due to a lack of monitoring and reporting as a result of restricted financial and logistical capacity. In developing countries, artisanal fisheries are the principal fishing practice and are consequently of considerable social and economic importance to regional human populations. These fisheries, however, can negatively impact the abundance and species composition of vulnerable species such as elasmobranchs (Pinnegar \& Engelhard 2008). Continued unregulated exploitation can lead to declines of key species with consequences extending to the broader food web, including commercial species that are critical to the livelihoods of local populations. Along the coast of Madagascar, elasmobranchs are heavily exploited both for subsistence (meat) and commercial (fins) purposes with an active and developed export market (McVean et al. 2006, Robinson \& Sauer 2013). Between October 2001 and October 2002, 13 species were identified from a total of 1164 individual elasmobranchs caught off the southwestern region of Madagascar. Hammerhead sharks (mostly Sphyrna lewini, and to a lesser extent $S$. mokarran and S. zygaena) represented $29 \%$ of the catch by number and $24 \%$ of the total wet weight with an estimate of over 123 metric tons landed (McVean et al. 2006). Hammerhead sharks (Sphyrna spp.) are globally threatened, with $S$. lewini currently classified as Endangered (IUCN Red List). Currently, no baseline ecological data exists for elasmobranchs from this region, but a decline in elasmobranch abundance has been observed for the most exploited species (McVean et al. 2006). This decline of elasmobranchs from the coastal waters of south-western Madagascar could have adverse effects on both fishing communities and marine ecosystems. To assess this possibility, there is a need for information on these species including their trophic interactions and levels of trophic redundancy in the elasmobranch community.

Nitrogen and carbon stable isotopes provide chemical tracers of the diets and foraging habitats of organisms in a given ecosystem. Because offshore or pelagic-derived food webs tend to be ${ }^{13} \mathrm{C}$-depleted compared to inshore or benthic food webs (Hobson 1999), carbon isotope values $\left(\delta^{13} \mathrm{C}\right)$ can be used to indicate the foraging habitat of a species. In addition, the relative position of the consumer in the food web can be estimated from nitrogen isotopes values $\left(\delta^{15} \mathrm{~N}\right)$ because of the enrichment of ${ }^{15} \mathrm{~N}$ through successive trophic transfers (Hobson 1999, Caut et al. 2009, Hussey et al. 2014). To date, carbon and nitrogen stable isotopes have been used to elucidate aspects of elasmobranch trophic and foraging ecology, including niche breadth and separation (Kinney et al. 2011, Speed et al. 2011, Vaudo \& Heithaus 2011, Heithaus et al. 2013), individual foraging specialization (Matich et al. 2011), and ontogenetic and sex variation in trophic interactions and habitat use (e.g. Hussey et al. 2011, Carlisle et al. 2012). Long-term integrated stable isotope values also provide information on the role of elasmobranchs within a food web (McMeans et al. 2010, Vaudo \& Heithaus 2011). In this study, we used stable isotopes to assess trophic relationships, isotopic niche breadth and overlap, as well as ontogenetic variation in trophic interactions among the most commonly caught elasmobranch species in artisanal fisheries operating in the coastal waters off south-western Madagascar (Table 1), including the scalloped hammerhead shark $S$. lewini, the sliteye shark Loxodon macrorhinus, the giant guitarfish Rhynchobatus djiddensis and the silky shark Carcharhinus falciformis.

\section{MATERIALS AND METHODS}

\section{Study sites and sample collection}

Shark samples were collected at 5 fish villages (landing sites) in south-western Madagascar: Andavadoaka, Nosy Be, Nosy Hao, Lamboara and Nosy Andriamitaroka (Fig. 1). Southern areas (Andavado- 
Table 1. Habitat, minimum depth range ('min depth') and major prey type ('diet') of elasmobranch species investigated in this study

\begin{tabular}{|c|c|c|c|c|}
\hline Species & Habitat & $\begin{array}{c}\text { Min } \\
\text { depth }(\mathrm{m})\end{array}$ & Diet & Reference \\
\hline Rhynchobatus djiddensis & Benthic & $0-200$ & $\begin{array}{l}\text { Small fishes, molluscs and } \\
\text { crustaceans }\end{array}$ & Darracott (1977), Compagno (1986) \\
\hline Loxodon macrorhinus & Demersal & $0-80$ & $\begin{array}{l}\text { Small demersal fishes and } \\
\text { cephalopods, crustaceans }\end{array}$ & Compagno (1984) \\
\hline Carcharhinus falciformis & $\begin{array}{l}\text { Epipelagic, } \\
\text { oceanic }\end{array}$ & $0-500$ & $\begin{array}{l}\text { Large squids, pelagic fishes, } \\
\text { pelagic crabs }\end{array}$ & $\begin{array}{l}\text { Compagno (1984), Bonfil (2008), } \\
\text { Cabrera-Chávez-Costa et al. (2010) }\end{array}$ \\
\hline Sphyrna lewini & Coastal, oceanic & $0-275$ & $\begin{array}{l}\text { Pelagic to demersal fishes, } \\
\text { squids and elasmobranchs }\end{array}$ & $\begin{array}{l}\text { Compagno (1984), Baum et al. (2007), } \\
\text { Hussey et al. (2011) }\end{array}$ \\
\hline
\end{tabular}

aka, Nosy Be, Nosy Hao, Lamboara) are characterised by 2 distinct fringing and barrier reef systems separated by a $5 \mathrm{~km}$ wide passage or channel in which several patch reefs are situated. The northern area (Nosy Andriamitaroka) is characterised by a shallow underwater shelf, approx. $30 \mathrm{~km}$ in width and generally less than $20 \mathrm{~m}$ deep. A scattered coral bank lies at the seaward periphery adjacent to the

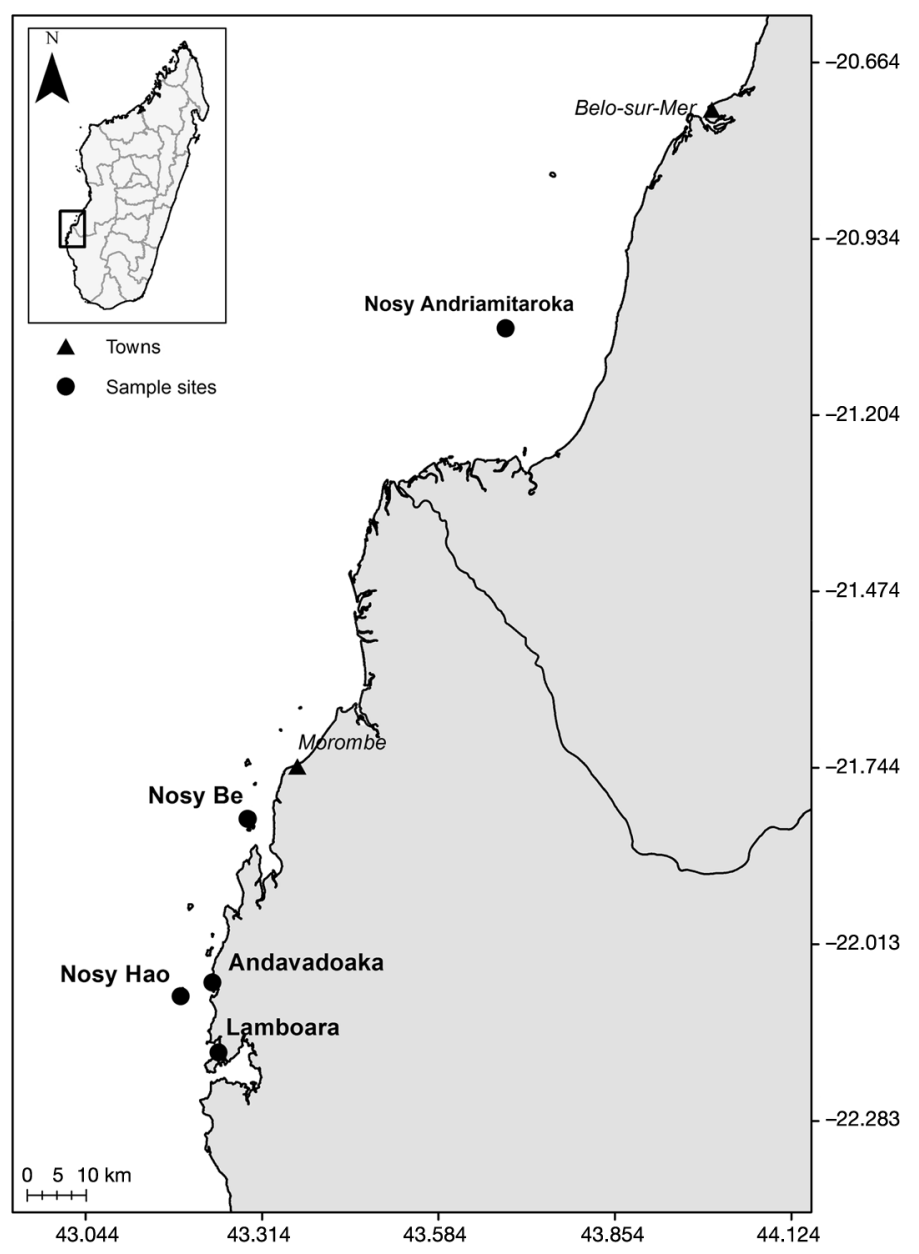

Fig. 1. The study area in south-western Madagascar continental shelf drop-off. Sharks were caught by traditional fishers using longlines and gillnets from traditional non-motorised sailing pirogues (6 to $8 \mathrm{~m}$ long). Longlines consisted of an anchor line 50 to $100 \mathrm{~m}$ long and a buoyed surface line, 50 to $100 \mathrm{~m}$ long, with three $12 \mathrm{~m}$ long snoods approx. $25 \mathrm{~m}$ apart which are attached to the surface line (McVean et al. 2006). Gillnets, the most commonly used gear, are approx. $50 \mathrm{~m}$ long and $4.5 \mathrm{~m}$ deep with a mesh size of 20 to $25 \mathrm{~cm}$. The nets are typically set on the bottom, in water approx. $30 \mathrm{~m}$ deep, and are generally baited with fish. Trained local data collectors surveyed the 5 fish landing sites year round from April 2009 to May 2010 to collect elasmobranch muscle samples for stable isotope analysis. White muscle tissue samples from the dorsal region of freshly landed sharks were collected from the most commonly recorded species, and were frozen at $-20^{\circ} \mathrm{C}$ until further processing. Basic morphometric measurements, including total and fork length (TL and FL, respectively) and sex were recorded for each individual sampled.

\section{Stable isotope analyses}

Elasmobranch white muscle tissue was freezedried, ground into a homogeneous powder and lipids were removed by 2 successive extractions ( $1 \mathrm{~h}$ shaking in cyclohexane at room temperature and subsequent centrifugation) prior to analysis to standardize data among individuals and across species within the food web (Hussey et al. 2012a). This process also removes urea and trimethylamine oxide (TMAO) present in shark tissues, which can potentially affect $\delta^{15} \mathrm{~N}$ values (Hussey et al. 2012b). A small sub-sample of tissue (0.35 to $0.45 \mathrm{mg}$ ) was weighed and stable isotope measurements performed with a continuous-flow isotope-ratio mass spectrometer (Delta V Advan- 
tage, Thermo Scientific) coupled to an elemental analyser (Flash EA1112, Thermo Scientific). Reference gases were calibrated against International Reference Materials (IAEA-N1, IAEA-N2 and IAEA-N3 for nitrogen; NBS-21, USGS-24 and IAEA-C6 for carbon). Results are expressed in the $\delta$ notation relative to PeeDee Belemnite and atmospheric $\mathrm{N}_{2}$ for $\delta^{13} \mathrm{C}$ and $\delta^{15} \mathrm{~N}$, respectively, according to the equation: $\delta X$ $=\left[\left(R_{\text {sample }} / R_{\text {standard }}\right)-1\right] \times 10^{3}$, where $X$ is ${ }^{13} \mathrm{C}$ or ${ }^{15} \mathrm{~N}$ and $R$ is the isotope ratio ${ }^{13} \mathrm{C} /{ }^{12} \mathrm{C}$ or ${ }^{15} \mathrm{~N} /{ }^{14} \mathrm{~N}$, respectively. Replicate measurements of a laboratory standard (acetanilide) indicated that analytical errors were $<0.1 \%$ for $\delta^{13} \mathrm{C}$ and $\delta^{15} \mathrm{~N}$. Percent $\mathrm{C}$ and $\mathrm{N}$ elemental composition of tissues were used to calculate the sample $\mathrm{C}: \mathrm{N}$ ratio, and indicated satisfactory lipid removal efficiency (mean $\pm \mathrm{SD} \mathrm{C}: \mathrm{N}=3.12 \pm 0.2$ ).

\section{Data analysis}

Assumptions regarding normality and homogeneity of variance were not met following Shapiro-Wilks and $F$ tests. Non-parametric Kruskal-Wallis $(H)$ tests were consequently used to examine the difference in stable isotopes values $\left(\delta^{15} \mathrm{~N}\right.$ and $\left.\delta^{13} \mathrm{C}\right)$ among species. Wilcoxon (W) signed rank tests were performed to assess differences in $\delta^{13} \mathrm{C}$ and $\delta^{15} \mathrm{~N}$ values between sexes and ANCOVA was used to test the influence of size and species on $\delta^{13} \mathrm{C}$ and $\delta^{15} \mathrm{~N}$ values of the 2 most commonly sampled species (S. lewini and $L$. macrorhinus). The ANCOVA is a general linear model with a continuous outcome variable $\left(\delta^{15} \mathrm{~N}\right.$ and $\delta^{13} \mathrm{C}$ values) and 2 or more predictor variables where at least one is continuous (size; FL) and at least one is categorical (species). In order to compare isotopic niches and infer habitat $\left(\delta^{13} C\right)$ and resource $\left(\delta^{15} N\right)$ separation among the 4 species, we used the recently developed SIBER metric (Stable Isotope Bayesian

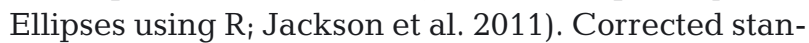
dard ellipses (SEAc) are calculated from the variance and covariance of the data matrix and represent core niche or dietary isotopic space while accounting for small sample sizes per species and variable sample sizes among species. The OVERLAP command within SIBER was used to calculate the percentage of core niche overlap among species $\delta^{13} \mathrm{C}$ and $\delta^{15} \mathrm{~N}$ ellipse space (Jackson et al. 2011). Data were analysed using R v. 2.12.0 (R Development Core Team 2010).

\section{RESULTS}

Over the 12 mo study period, 84 Loxodon macrorhinus, 40 Sphyrna lewini, 20 Rhynchobatus djiddensis and 7 Carcharhinus falciformis samples were obtained. The size range of individuals sampled was highly variable among species, with juveniles making up the majority of individuals, especially for $S$. lewini and $R$. djiddensis (Table 2, Fig. 2). The $\delta^{13} \mathrm{C}$ value was lowest for $S$. lewini (mean \pm SD; $-15.9 \pm$ $1.19 \%$ ) and highest for C. falciformis (-14.4 $\pm 2 \%$ ), while the mean $\delta^{15} \mathrm{~N}$ was lowest for L. macrorhinus $(11.7 \pm 0.59 \%)$ and the highest for C. falciformis (12.9 $\pm 1.36 \%$; Table 2). Stable isotope values found in this study were graphically compared to other teleost fishes with known trophic level and habitat (see Daly et al. 2013), including offshore pelagic, coastal pelagic and coastal demersal species (Fig. 3). Based on these data, C. falciformis and S. lewini do not have truly oceanic isotopic values. Conversely, it seems that $L$. macrorhinus and $R$. djiddensis are coastal consumers foraging in benthic and inshore habitats (Fig. 3).

Mean isotopic values varied among the 4 species for both $\delta^{13} \mathrm{C}(H=10.8 ; \mathrm{df}=3 ; \mathrm{p}=0.01)$ and $\delta^{15} \mathrm{~N}$ $(H=10.8 ; \mathrm{df}=3 ; \mathrm{p}=0.01$; Fig. 3$)$. At the individual level, $\delta^{13} \mathrm{C}$ and $\delta^{15} \mathrm{~N}$ data were tightly clustered for $L$. macrorhinus and $R$. djiddensis but were more dispersed for $S$. lewini and C. falciformis (Figs. $3 \& 4$ ). Isotopic ellipse size was highly variable among species, with $R$. djiddensis having the smallest isotopic niche (0.3) and C. falciformis the largest (5.4) (Fig. 4). Ellipse sizes for $S$. lewini and L. macrorhinus were

Table 2. Number of sampled sharks (n), mean and range fork length, sex ratio, percentage of mature individuals in sampling of our study based on length of maturity from Compagno (1984), and mean \pm SD values for stable nitrogen and carbon isotopes and $\mathrm{C}: \mathrm{N}$ ratios

\begin{tabular}{|c|c|c|c|c|c|c|c|c|}
\hline Species & $\mathrm{n}$ & $\begin{array}{l}\text { Fork le } \\
\text { Mean }\end{array}$ & $\begin{array}{c}\text { gth }(\mathrm{cm}) \\
\text { Range }\end{array}$ & $\begin{array}{l}\text { Sex ratio } \\
\text { (m:f) }\end{array}$ & $\begin{array}{c}\% \text { of } \\
\text { mature ind. }\end{array}$ & $\begin{array}{c}\delta^{15} \mathrm{~N} \\
\text { Mean } \pm \mathrm{SD}\end{array}$ & $\begin{array}{c}\delta^{13} \mathrm{C} \\
\text { Mean } \pm \mathrm{SD}\end{array}$ & $\begin{array}{c}\mathrm{C}: \mathrm{N} \\
\text { Mean } \pm \mathrm{SD}\end{array}$ \\
\hline Loxodon macrorhinus & 84 & 83.7 & $62-100$ & $1: 1$ & 85 & $11.66 \pm 0.59$ & $-15.4 \pm 1.01$ & $3.14 \pm 0.18$ \\
\hline Carcharhinus falciformis & 7 & 162.9 & $73-260$ & $0.9: 1$ & 29 & $12.89 \pm 1.36$ & $-14.37 \pm 1.2$ & $3.02 \pm 0.1$ \\
\hline Rhynchobatus djiddensis & 20 & 86 & $65-190$ & $0.8: 1$ & 5 & $11.92 \pm 0.42$ & $-14.66 \pm 0.43$ & $3.13 \pm 0.1$ \\
\hline Sphyrna lewini & 40 & 96.5 & $58-172$ & $0.8: 1$ & 5 & $12.42 \pm 1.05$ & $-15.89 \pm 1.19$ & $3.1 \pm 0.2$ \\
\hline
\end{tabular}




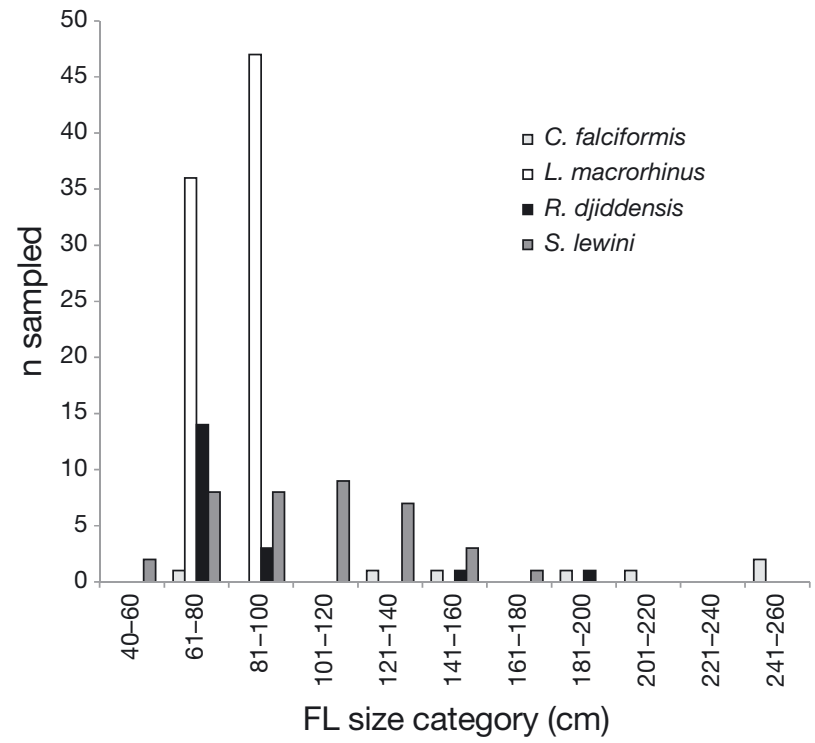

Fig. 2. Fork length (FL) distribution of Carcharhinus falciformis, Loxodon macrorhinus, Rhynchobatus djiddensis and Sphyrna lewini sampled off SW Madagascar from 2009 to 2010

4.1 and 1.9, respectively. Isotope niche overlap, based on the measure of ellipse overlap was high for $R$. djiddensis compared with C. falciformis (93.2\%) and L. macrorhinus (73.2\%), and to a lesser extent $S$. lewini $(13.3 \%$, Table 3$)$. Higher isotopic niche overlap was also found between $L$. macrorhinus and both S. lewini $(48.3 \%)$ and C. falciformis $(46.2 \%)$, but most other comparisons yielded low niche overlap values (Fig. 4; Table 3).

For $S$. lewini and L. macrorhinus, ANCOVA confirmed that the 2 species were significantly distinct in their $\delta^{15} \mathrm{~N}$ values, and that there was an effect of individual size $\left(F_{3,116}=30.75, \mathrm{p}<0.0001\right.$, Fig. 5). Smaller individuals of both species had similar $\delta^{15} \mathrm{~N}$ values, but there was an increase in $\delta^{15} \mathrm{~N}$ with size in $S$. lewini $\left(\mathrm{R}^{2}=\right.$ $0.49, \mathrm{p}<0.0001$ ) that was not observed in the smaller-bodied $L$. macrorhinus. In contrast, ANCOVA found no influence of species and size on $\delta^{13} \mathrm{C}$ values $\left(F_{3,116}=\right.$ $2.05, \mathrm{p}=0.11_{\text {; Fig. 5). Intraspecific varia- }}$ tion in $\delta^{15} \mathrm{~N}$ and $\delta^{13} \mathrm{C}$ values was high for both S. lewini and L. macrorhinus (Table 2; Fig. 5), especially for $\delta^{13} C_{\text {, highlighting }}$ potentially inter-individual differences in diets and/or foraging habitats. There was no difference between male and female $\delta^{13} \mathrm{C}$ values for either species $(S$. lewini: $\mathrm{W}=161.5 ; \mathrm{p}=0.60$ and $L$. macrorhinus: $\mathrm{W}=871.5 ; \mathrm{p}=0.77$ ) or for $\delta^{15} \mathrm{~N}$ values of $S$.

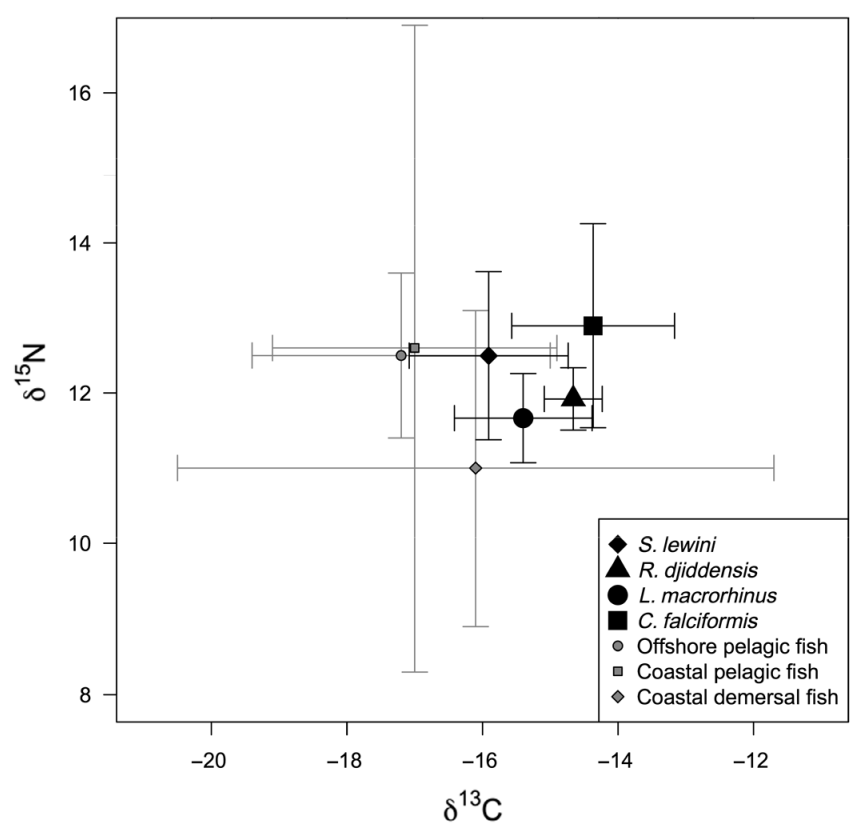

Fig. 3. Stable isotope values $\left(\delta^{15} \mathrm{~N}\right.$ and $\left.\delta^{13} \mathrm{C}, \%\right)$ in elasmobranch muscle (mean $\pm \mathrm{SD}$ ) from Madagascar (this study) compared to teleost fishes from offshore pelagic, coastal pelagic and coastal demersal habitats (from Daly et al. 2013)

lewini ( $\mathrm{W}=150 ; \mathrm{p}=0.39)$. For L. macrorhinus, males had significantly higher $\delta^{15} \mathrm{~N}$ values (mean $=11.8 \pm$ $0.54 \%$ ) than females $($ mean $=11.5 \pm 0.62 \%$; $\mathrm{W}=675$; $\mathrm{p}=0.04)$.

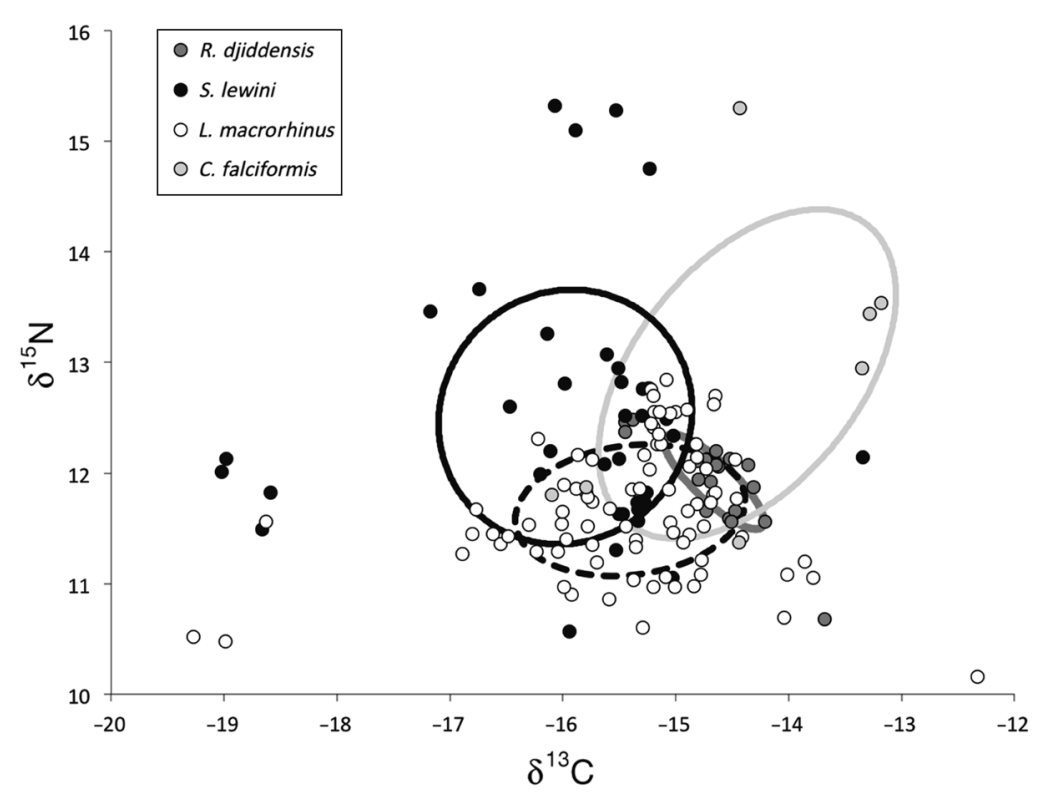

Fig. 4. Individual stable isotope values $\left(\delta^{15} \mathrm{~N}\right.$ and $\left.\delta^{13} \mathrm{C}, \%\right)$ and corrected standard ellipses (SEAc) for Carcharhinus falciformis (light grey continuous line), Loxodon macrorhinus (black dashed line), Rhynchobatus djiddensis (dark grey continuous line) and Sphyrna lewini (black continuous line) 
Table 3. Percentage of isotopic niche overlap $\left(\delta^{15} \mathrm{~N}\right.$ vs $\left.\delta^{13} \mathrm{C}\right)$ based on corrected standard ellipses (SEAc) for the 4 species investigated. Two-way overlap values are presented for species comparisons, i.e. a value for $R$. djiddensis overlap with C. falciformis (93.2\%) and C. falciformis overlap with R. djiddensis $(5.7 \%)$

\begin{tabular}{|lcccc|}
\hline & $\begin{array}{c}\text { Rhynchobatus } \\
\text { djiddensis }\end{array}$ & $\begin{array}{c}\text { Loxodon } \\
\text { macrorhinus }\end{array}$ & $\begin{array}{c}\text { Sphyrna } \\
\text { lewini }\end{array}$ & $\begin{array}{c}\text { Carcharhinus } \\
\text { falciformis }\end{array}$ \\
\hline R. djiddensis & - & 12.8 & 1.1 & 5.7 \\
L. macrorhinus & 73.2 & - & 22.4 & 16.1 \\
S. lewini & 13.3 & 48.3 & - & 19.3 \\
C. falciformis & 93.2 & 46.2 & 26.6 & - \\
\hline
\end{tabular}

\section{DISCUSSION}

These data provide the first investigation of trophic interactions, isotopic niches, ontogenetic and gender variation in the foraging ecology of 4 heavily exploited elasmobranch species from a data-poor region, the Mozambique Channel off south-western Madagascar. Sphyrna lewini, Loxodon macrorhinus, Rhynchobatus djiddensis and Carcharhinus falciformis are among the most commonly caught species by artisanal fishers over continental shelf waters in this region $(\sim 75 \%$ of species landed in the sampled region; F. Humber unpubl. data), and likely constitute a large proportion of the elasmobranch biomass. These species also account for a high percentage of the catch of artisanal fisheries off northern Madagascar, where concern over exploitation rates has recently been documented (Robinson \& Sauer 2013). Sampling covered a range of sizes (FL range 62 to
$260 \mathrm{~cm}$ ) for L. macrorhinus and C. falciformis, but consisted of mostly juvenile $S$. lewini and $R$. djiddensis, likely reflecting artisanal shark fisheries overlapping with nursery areas. It is possible, however, that long-term exploitation of elasmobranchs in this region, primarily for the fin trade, has altered the size structure of populations.

In order to correctly interpret stable isotope values in the tissues of juvenile sharks, especially those with long turnover rates (e.g. muscle), it is critical to understand the dynamics of maternal provisioning (McMeans et al. 2010). Previous studies of mother-offspring differences of stable isotopes ratios in placentatrophic sharks have shown that embryos are generally enriched in $\delta^{15} \mathrm{~N}$ but fractionation of $\delta^{13} \mathrm{C}$ is variable among species (McMeans et al. 2009, Vaudo et al. 2010). Based on data from the literature (size at birth and growth parameters; Compagno 1984, 1986), all animals from our study were likely more than $1 \mathrm{yr}$ old. Therefore, maternal influences should have very limited impacts on isotopic values of the individuals in this study.

Stable isotope data indicated that, although the 4 species differed in their relative trophic position (indicated by mean $\delta^{15} \mathrm{~N}$ values), $\delta^{13} \mathrm{C}$ values suggested considerable overlap in the food webs where species were foraging. There were, however, differences in how trophic interactions varied with size for $S$. lewini and L. macrorhinus and between sexes of L. macrorhinus. The 4 focal species are morphologi-
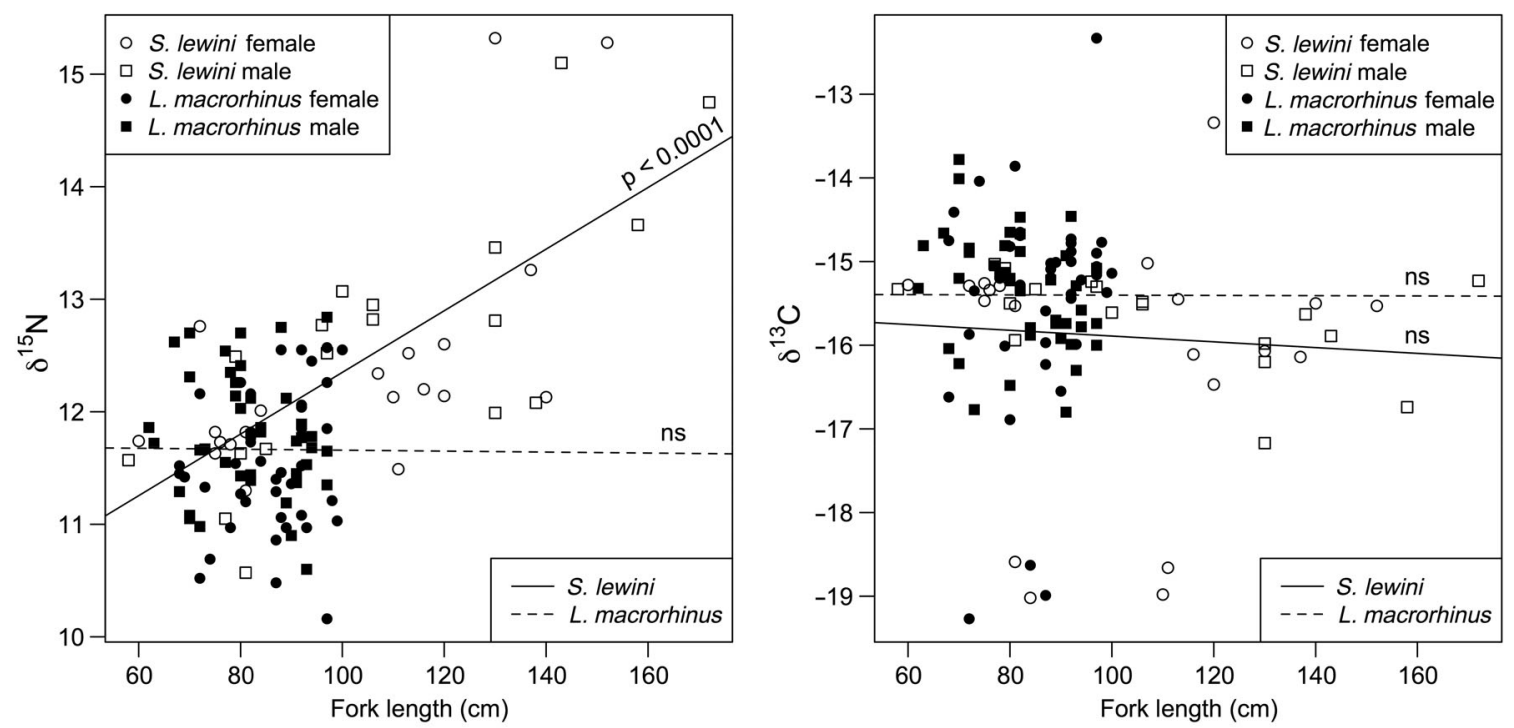

Fig. 5. Relationships between $\delta^{15} \mathrm{~N}$ and $\delta^{13} \mathrm{C}$ and fork length in Sphyrna lewini and Loxodon macrorhinus males and females. Significance for $\mathrm{r}^{2}$ values: $\mathrm{p}<0.0001$ and not significant, $\mathrm{ns}$ 
cally and ecologically distinct in terms of body size and feeding apparatus, diet consumed, and habitat use patterns (see Table 1). C. falciformis and S. lewini are wide-ranging and occur in oceanic, epipelagic and continental shelf habitats. They feed mostly on epipelagic and pelagic fish, cephalopods and crustaceans (Compagno 1984, Bonfil 2008). Juvenile $S$. lewini reside in coastal nursery grounds (Simpfendorfer \& Milward 1993) that probably extend over the continental shelf off south-western Madagascar, as observed off south-eastern Africa (Diemer et al. 2011). $R$. djiddensis also occurs over the continental shelf, but, in contrast to $S$. lewini and C. falciformis, is adapted to shallow coastal waters (i.e. closer to more ${ }^{13} \mathrm{C}$-enriched benthic sources) and is thought to have relatively restricted home range and to feed mostly on molluscs and crustaceans (Darracott 1977, Compagno 1986). L. macrorhinus is a poorly known continental shelf species that lives in intertidal areas up to $80 \mathrm{~m}$ depth and which feeds on teleosts, coastal cephalopods and crustaceans (Compagno 1984). Despite these marked differences, there was considerable overlap in $\delta^{13} \mathrm{C}$ values among the 4 species. The larger variation in $\delta^{13} \mathrm{C}$ values observed in $L$. macrorhinus and $S$. lewini compared to $R$. djiddensis likely indicate the diversity of habitats and feeding areas encountered with larger home ranges, especially for the more pelagic $S$. lewini. The inability of $\delta^{13} \mathrm{C}$ values to discriminate known interspecific variation in seasonal fine-scale vertical (pelagic vs. benthic) and horizontal (oceanic vs. coastal) distributions likely relates to the slow turnover rate of muscle tissue ( $>250$ d; Kim et al. 2012). Such limitations of carbon isotopes in resolving fine-scale foraging patterns of seabirds and marine mammals have been reported in various ecological contexts (Cherel et al. 2008, Méndez-Fernandez et al. 2012). For example, despite obvious differences in habitat preferences of small cetaceans off the Iberian Peninsula (e.g. depth distributions; Pierce et al. 2010), similar $\delta^{13} \mathrm{C}$ values were recorded among species (Méndez-Fernandez et al. 2012).

Unfortunately, isotopic data on prey from specific habitats and food webs could not be collected during our study. Such data would provide even greater insights into the diets, foraging habitats and home ranges of the species studied here (e.g. Daly et al. 2013, Kiszka et al. 2014). However, data from neighbouring areas (e.g. coastal waters of Mozambique; Daly et al. 2013) can provide insights into habitat use by our focal species off SW Madagascar. Based on these regional data, none of the most pelagic species, especially C. falciformis and S. lewini had truly oceanic isotopic values. Indeed, both species from south-western Madagascar had higher $\delta^{13} \mathrm{C}$ values than those measured in pelagic teleosts (Daly et al. 2013). This pattern is similar to published data on carbon and nitrogen isotope values from the same region for C. falciformis. Both $\delta^{15} \mathrm{~N}$ and $\delta^{13} \mathrm{C}$ were significantly higher for $C$. falciformis off south-western Madagascar than was found further north in the Mozambique Channel (Rabehagasoa et al. 2012; see Table 2). This could be due to spatial variation in diets of C. falciformis in this region. However, the individuals we sampled were significantly larger than those analysed by Rabehagasoa et al. (2012). Therefore, ontogenetic shifts in diets, which have been documented for this species (Compagno 1984, Cabrera-Chávez-Costa et al. 2010, Rabehagasoa et al. 2012), may also explain the observed differences with C. falciformis feeding on higher trophic level prey at larger sizes. Moreover, higher $\delta^{13} \mathrm{C}$ values observed in this species in our study area may either reflect an increasing relative importance of coastal prey with age, or a larger prevalence of coastal prey in the diet of $C$. falciformis (where the continental shelf is broader). In contrast, based on a comparison of data from a variety of pelagic and coastal teleost fish species from the coastal waters of Mozambique, it seems that $L$. macrorhinus and $R$. djiddensis are truly coastal consumers foraging in inshore and benthic habitats (Daly et al. 2013). Interestingly, $\delta^{13} \mathrm{C}$ values measured in $S$. lewini and $R$. djiddensis from south-western Madagascar were similar to those from north-western India (Borrell et al. 2011) and KwaZulu-Natal, South Africa (for S. lewini only; Hussey et al. 2011). However, $\delta^{15} \mathrm{~N}$ values of both $S$. lewini and $R$. djiddensis were significantly lower off south-western Madagascar (Table 2), compared to those measured in India for the same species (Borrell et al. 2011). This regional variation highlights the need for region-specific isotopic data to evaluate the trophic interactions, including for wide-ranging consumers such as large elasmobranchs.

Differences in trophic interactions among these 4 highly exploited elasmobranchs suggest these species are not trophically redundant. This is consistent with previous studies from other geographic locations, where elasmobranchs were segregated based on their relative trophic position or mean $\delta^{15} \mathrm{~N}$ values (Cortés 1999, Borrell et al. 2011, Heithaus et al. 2013, Hussey et al. 2014). Such isotopic segregation within a community has been documented in a number of coastal, oceanic and reef-associated elasmobranch species (e.g. Kinney et al. 2011, Speed et al. 2011, Rabehagasoa et al. 2012), but not in assemblages 
where species show morphological, taxonomic and habitat similarities over small spatial scales (Vaudo \& Heithaus 2011). The highest degree of overlap in $\delta^{15} \mathrm{~N}$ values was found between individuals of $R$. djiddensis and L. macrorhinus, species that both occur in shallow waters of the continental shelf. Overlap in diet would therefore be expected, although finescale niche partitioning (concealed by isotope analyses) may occur. Detailed stomach content data collected over a seasonal cycle would be required to determine this. S. lewini and L. macrorhinus also exhibited a moderately high degree of niche overlap, but the former had a significantly higher mean $\delta^{15} \mathrm{~N}$ value (related to an ontogenetic diet shift with size). Juvenile $S$. lewini and L. macrorhinus of all size classes had similar $\delta^{15} \mathrm{~N}$ values, also related to their occurrence in coastal waters and the potential for high niche overlap. It is important to note that establishing isotopic baselines and system end points for carbon and nitrogen stable isotopes in this region would be required to further elucidate the trophic ecology and roles of these species. The isotopic niche sizes varied among species, with $\delta^{15} \mathrm{~N}$ and $\delta^{13} \mathrm{C}$ values tightly clustered for $L$. macrorhinus and $R$. djiddensis but more dispersed for S. lewini and C. falciformis. The large variability in $S$. lewini and $L$. macrorhinus isotopic values may indicate either a high level of generalist feeding behaviour or, more likely, because of the long turnover times of muscle tissue, consistent differences in average trophic interactions of individuals within generalist populations. Such behaviour has been found in juvenile bull sharks C. leucas in a nursery area of Florida (Matich et al. 2011) and has been suggested for a number of other elasmobranch taxa such as batoids (Vaudo \& Heithaus 2011). In contrast, L. macrorhinus and $R$. djiddensis may be more specialized at the population level or individuals may all have similarly generalized diets over the time period that muscle isotopic values are integrated. The small sample size for $C$. falciformis may have influenced the standard ellipse (SEAc) size through artificially inflating the size of the niche area (Jackson et al. 2011). Given the observed variability in the data, however, this bias is likely minimal. Stable isotope analyses of multiple tissues with different turnover rates would address questions related to individual foraging specialisation (Matich et al. 2011) and elucidate more intricate seasonal differences (Kinney et al. 2011).

Ontogenetic and sex differences in diets and habitat preferences are related to age- and sex-specific energy requirements, vulnerability to predators, and social considerations, and have been documented for a diversity of taxa (e.g. Beier 1987, Breed et al. 2006), including elasmobranchs (Lowe et al. 1996, Estrada et al. 2006, Hussey et al. 2011, Rabehagasoa et al. 2012). Such ontogenetic niche shifts can impact population dynamics, community structure, and ecosystem function (Hammerschlag-Peyer et al. 2011, Hussey et al. 2011). Relative trophic level, inferred by $\delta^{15} \mathrm{~N}$ values, significantly increased with body length in $S$. lewini, suggesting a dietary change with age in this species that likely reflects moving from more coastal to pelagic habitats and foraging on higher trophic level prey (Compagno 1984, Borrell et al. 2011, Hussey et al. 2011). Spatial segregation has been documented for a diversity of elasmobranch species (Compagno 1984), including through the use of stable isotopes (e.g. Hussey et al. 2011). In our study, differences in $\delta^{15} \mathrm{~N}$ values between male and female $L$. macrorhinus indicate that males feed at a higher relative trophic position compared to females. Whether this reflects foraging on different prey taxa or sexual segregation remains to be elucidated. We did not detect sex differences in isotopic values of S. lewini, which contrasts with results from individuals captured off the coast of KwaZulu-Natal, South Africa (Hussey et al. 2011). Off South Africa, $\delta^{13} \mathrm{C}$ values of males and females between 120 and $160 \mathrm{~cm}$ (precaudal length) supported sexual segregation, with females most likely spending more time in oceanic waters (Hussey et al. 2011).

\section{CONCLUSIONS}

In summary, these data suggest that complex trophic structuring occurs in this highly exploited elasmobranch assemblage. Differences in trophic interactions appear to be driven by a combination of interacting factors including habitat use, home-range size, diets, and variation in all of these factors across size classes, sexes and individual behaviours. Consequently, species-specific population declines as a result of continued unregulated exploitation have the potential to lead to intricate species-specific cascades within the coastal waters of south-western Madagascar. More detailed sampling of the food web, however, is required to examine isotopic variation in prey items consumed by the 4 species and to determine if benthic and pelagic and coastal/offshore ecosystems can be readily distinguished. Given the IUCN Red list categories for 2 of the species ('Vulnerable', $R$. djiddensis; 'Endangered', S. lewini), local management is imperative to regulate regional fisheries. More data is also required on the biological para- 
meters of these populations and other large predators in the system to incorporate in food web models to examine long-term effects of removing trophically distinct species within artisanal fisheries.

Acknowledgements. Our particular thanks are addressed to sample and data collectors in south-western Madagascar, working on behalf of Blue Ventures. We are grateful to G. Guillou and P. Richard (University of La Rochelle, UMR LIENSs), for running the stable isotope analyses. This work has been supported financially by LIENSs and the CPER 13 (Contrat de Projet Etat-Région).

\section{LITERATURE CITED}

Baum J, Clarke S, Domingo A, Ducrocq M and others (2007) Sphyrna lewini. In: IUCN 2012. IUCN Red List of Threatened Species. Version 2012.2. www.iucnredlist.org

Beier P (1987) Sex differences in quality of white-tailed deer diets. J Mammal 68:323-329

Bonfil R (2008) The biology and ecology of the silky shark, Carcharhinus falciformis. In: Camhi MD, Pikitch EK, Babcock EA (eds) Sharks of the open ocean. Blackwell, Oxford, p 114-127

> Borrell A, Cardona L, Kumarran RP, Aguilar A (2011) Trophic ecology of elasmobranchs caught off Gujarat, India, as inferred from stable isotopes. ICES J Mar Sci 68: 547-554

> Breed GA, Bowen WD, McMillan JI, Leonard ML (2006) Sexual segregation of seasonal foraging habitat in a nonmigratory marine mammal. Proc R Soc Lond Ser B Biol Sci 273:2319-2326

Burkholder DA, Heithaus MR, Fourqurean JW, Wirsing A, Dill LM (2013) Patterns of top-down control in a seagrass ecosystem: Could a roving apex predator induce a behaviour-mediated trophic cascade? J Anim Ecol 82: 1192-1202

Cabrera-Chávez-Costa AA, Galván-Magaña F, EscobarSánchez OE (2010) Food habits of the silky shark Carcharhinus falciformis (Müller \& Henle, 1839) off the western coast of Baja California Sur, Mexico. J Appl Ichthyol 26:499-503

Carlisle AB, Kim SL, Semmens BX, Madigan DJ and others (2012) Using stable isotope analysis to understand the migration and trophic ecology of northeastern Pacific white sharks (Carcharodon carcharias). PLoS ONE 7: e30492

> Caut S, Angulo E, Courchamp F (2009) Variation in discrimination factors $\left(\Delta^{15} \mathrm{~N}\right.$ and $\left.\Delta^{13} \mathrm{C}\right)$ : the effect of diet isotopic values and applications for diet reconstruction. J Appl Ecol 46:443-453

Cherel Y, Le Corre M, Jaquemet S, Ménard F, Richard P, Weimerskirch H (2008) Resource partitioning within a tropical seabird community: new information from stable isotopes. Mar Ecol Prog Ser 366:281-291

Compagno LJV (1984) FAO species catalogue, Vol. 4. Sharks of the world. An annotated and illustrated catalogue of shark specimen known to date. Part 2. Carcharhiniformes. FAO Fish Synop 125:251-655

Compagno LJV (1986) Rhinobatidae. In: Smith MM, Heemstra PC (eds) Smiths' sea fishes. Springer-Verlag, Berlin, p 128-131
Cortés E (1999) Standardized diet compositions and trophic levels of sharks. ICES J Mar Sci 56:707-717

Daly R, Froneman PW, Smale MJ (2013) Comparative feeding ecology of bull sharks (Carcharhinus leucas) in the coastal waters of the southwest Indian Ocean inferred from stable isotope analysis. PLoS ONE 8:e78229

> Darracott A (1977) Availability, morphometrics, feeding and breeding activity in a multi-species, demersal fish stock of the Western Indian Ocean. J Fish Biol 10:1-16

$>$ Diemer KM, Mann BQ, Hussey NE (2011) Distribution and movement of scalloped hammerhead Sphryna lewini and smooth hammerhead Sphyrna zygaena sharks along the east coast of southern Africa. Afr J Mar Sci 33: $229-238$

> Dulvy NK, Baum JK, Clarke S, Compagno LJV and others (2008) You can swim but you can't hide: the global status of and conservation of pelagic sharks and rays. Aquat Conserv 18:459-482

Estes JA, Terborgh J, Brashares JS, Power ME and others (2011) Trophic downgrading of planet earth. Science 333:301-306

Estrada JA, Rice AN, Natanson NJ, Skomal GB (2006) Use of isotopic analysis from vertebrae in reconstructing ontogenetic feeding ecology in white sharks. Ecology 87 : 829-834

Ferretti F, Worm B, Britten GL, Heithaus MR, Lotze HK (2010) Patterns and ecosystem consequences of shark declines in the ocean. Ecol Lett 13:1055-1071

Hammerschlag-Peyer CM, Yeager LA, Araújo MS, Layman CA (2011) A hypothesis-testing framework for studies investigating ontogenetic niche shifts using stable isotope ratios. PLoS ONE 6:e27104

> Heithaus MR, Frid A, Wirsing AJ, Worm B (2008) Predicting ecological consequences of marine top predator declines. Trends Ecol Evol 23:202-210

Heithaus MR, Frid A, Vaudo JJ, Worm B, Wirsing AJ (2010) Unravelling the ecological importance of elasmobranchs. In: Carrier JC, Musick JA, Heithaus MR (eds) Sharks and their relatives. II. Biodiversity, adaptative physiology and conservation. CRC Press, Boca Raton, FL, p 611-636

Heithaus MR, Vaudo J, Kreicker S, Layman CA and others (2013) Apparent resource partitioning and trophic structure of large-bodied predators in a relatively pristine seagrass ecosystem. Mar Ecol Prog Ser 481:225-237

> Hobson KA (1999) Tracing origins and migration of wildlife using stable isotopes: a review. Oecologia 120:314-326

- Hussey NE, Dudley SFJ, McCarthy ID, Cliff G, Fisk AT (2011) Stable isotope profiles of large marine predators: viable indicators of trophic position, diet and movement in sharks? Can J Fish Aquat Sci 68:2029-2045

Hussey NE, Olin JA, Kinney MJ, McMeans BC, Fisk AT (2012a) Lipid extraction effects on stable isotope values $\left(\delta^{13} \mathrm{C}\right.$ and $\left.\delta^{15} \mathrm{~N}\right)$ of elasmobranch muscle tissue. J Exp Mar Biol Ecol 434-435:7-15

- Hussey NE, MacNeil MA, Olin JA, McMeans BC, Kinney MJ, Chapman DD, Fisk AT (2012b) Stable isotopes and elasmobranchs: tissue types, methods, applications and assumptions. J Fish Biol 80:1449-1484

Hussey NE, MacNeil MA, McMeans BC, Olin JA and others (2014) Rescaling the trophic structure of marine food webs. Ecol Lett 17:239-250

Jackson AL, Inger R, Parnell AC, Bearhop S (2011) Comparing isotopic niche widths among and within communities: SIBER - Stable Isotope Bayesian Ellipses in R. J Anim Ecol 80:595-602 
Kim SL, del Rio CM, Casper D, Koch PL (2012) Isotopic incorporation rates for shark tissues from a long-term captive feeding study. J Exp Biol 215:2495-2500

Kinney MJ, Hussey NE, Fisk AT, Tobin AJ, Simpfendorfer CA (2011) Communal or competitive? Stable isotope analysis provides evidence of resource partitioning within a communal shark nursery. Mar Ecol Prog Ser 439:263-276

Kiszka J, Méndez-Fernandez P, Heithaus MR, Ridoux V (2014) The foraging ecology of coastal bottlenose dolphins based on stable isotope mixing models and behavioural sampling. Mar Biol 161:953-961

Lowe C, Wetherbee BM, Crow GL, Tester AL (1996) Ontogenetic dietary shifts and feeding behavior of tiger sharks, Galeocerdo cuvier, in Hawaiian waters. Environ Biol Fishes 47:203-211

Matich P, Heithaus MR, Layman CA (2011) Contrasting patterns of individual foraging specialization and trophic coupling in two marine apex predators. J Anim Ecol 80: 294-305

McMeans BC, Olin JA, Benz GW (2009) Stable-isotope comparisons between embryos and mothers of a placentatrophic shark species. J Fish Biol 75:2464-2474

McMeans BC, Svavarsson J, Dennard S, Fisk A (2010) Diet and resource use among Greenland sharks (Somniosus microcephalus) and teleosts sampled in Icelandic waters using $\delta^{13} \mathrm{C}, \delta^{15} \mathrm{~N}$, and mercury. Can J Fish Aquat Sci 67 : $1428-1438$

McVean AR, Walker SCJ, Fanning E (2006) The traditional shark fisheries of southwest Madagascar: a study in the Toliara region. Fish Res 82:280-289

Méndez-Fernandez P, Bustamante P, Bode A, Chouvelon T and others (2012) Foraging ecology of five toothed whale species in the Northwest Iberian Peninsula, inferred using $\delta^{13} \mathrm{C}$ and $\delta^{15} \mathrm{~N}$ isotopic signatures. J Exp Mar Biol Ecol 413:150-158

Myers RA, Baum JK, Shepherd TD, Powers SP, Peterson PH (2007) Cascading effects of the loss of apex predatory sharks for a coastal ocean. Science 315:1846-1850

Pauly D (2006) Major trends in small-scale fisheries, with emphasis on developing countries, and some implica-

Editorial responsibility: Christine Paetzold,

Oldendorf/Luhe, Germany tions for the social sciences. Marit Stud 4:7-22

Pierce GJ, Caldas M, Cedeira J, Santos MB and others (2010) Trends in cetacean sightings along the Galician coast, north-west Spain, 2003-2007, and inferences about cetacean habitat preferences. J Mar Biol Assoc UK 90: 1547-1560

Pinnegar JK, Engelhard GH (2008) The shifting baseline phenomenon: a global perspective. Rev Fish Biol Fish 18: $1-16$

R Development Core Team (2010) R: A language and environment for statistical computing. R Foundation for Statistical Computing, Vienna

Rabehagasoa N, Lorrain A, Bach P, Potier M, Jaquemet S, Richard P, Ménard F (2012) Isotopic niches of the blue shark Prionace glauca and the silky shark Carcharhinus falciformis in the southwestern Indian Ocean. End Spec Res 17:83-92

Robinson J, Sauer WHH (2013) A first description of the artisanal shark fishery in northern Madagascar: implications for management. Afr J Mar Sci 35:9-15

Simpfendorfer CA, Milward NE (1993) Utilisation of a tropical bay as a nursery area by sharks of the families Carcharhinidae and Sphyrnidae. Environ Biol Fishes 37: 337-345

Speed CW, Meekan MG, Field IC, McMahon CR, Abrantes K, Bradshaw CJA (2011) Trophic ecology of reef sharks determined using stable isotopes and telemetry. Coral Reefs 31:357-367

Vaudo JJ, Heithaus MR (2011) Dietary niche overlap in a nearshore elasmobranch mesopredator community. Mar Ecol Prog Ser 425:247-260

> Vaudo JJ, Matich P, Heithaus MR (2010) Mother-offspring isotope fractionation in two species of placentatrophic sharks. J Fish Biol 77:1724-1727

Wetherbee B, Cortés E (2004) Food consumption and feeding habits. In: Carrier JC, Musick JA, Heithaus MR (eds) Sharks and their relatives. CRC Press, Boca Raton, FL, p 225-246

Worm B, Davis B, Ketterner L, Ward-Paige CA and others (2013) Global catches, exploitation rates, and rebuilding options for sharks. Mar Policy 40:194-204

Submitted: March 31, 2014; Accepted: September 3, 2014

Proofs received from author(s): November 2, 2014 